Nippon Suisan Gakkaishi $\quad \mathbf{5 7 ( 1 0 ) , ~ 1 9 5 7 - 1 9 6 3 ~ ( 1 9 9 1 ) ~}$

\title{
マサバ筋原線維の加熱変性に対する直鎖オりゴ糖 および還元直鎖オリゴ糖の抑制作用*1
}

\author{
三浦 靖, 西村彰夫, 高柳敏紀
}

(1991 年 5 月 24 日受付)

\begin{abstract}
Protective Effect of Linear Oligosaccharides and Hydrogenated Linear
Oligosaccharides on the Thermal Denaturation of

Chub Mackerel Myofibrils*1

Makoto Miura,*2 Akio Nishimura,*2 and Toshinori Takayanagi*3
\end{abstract}

\begin{abstract}
The protective effects of linear oligosaccharides and hydrogenated linear oligosacharides on thermal denaturation of crub mackerel myofibrillar proteins at $35^{\circ} \mathrm{C}$ and at $\mathrm{pH} 7.5$ were studied by measuring the apparent rate constant of inactivation of their Ca-ATPase.

It was found that the protective effects of linear oligosaccharides (DE $45, \overline{\mathrm{DP}}_{n} 2.7$ ) and hydrogenated linear oligosaccharides $\left.\overline{\left(\mathrm{DP}_{n}\right.} 2.7\right)$ were similar to those of sucrose and $\mathrm{D}$-sorbitol. It was also suggested that the mean number of equatorial hydroxy groups, the mean degree of polymerization, and the distribution of degree of polymerization in the oligosaccharide molecules were important factors for evaluation of the protective effect against thermal denaturation of the myofibrillar proteins.
\end{abstract}

\footnotetext{
グリセロールやソルビトールなどの直鎖ボリオールや スクロースなどの糖などのいわゆるポリオールの添加に より,タンパク質の変性や䣼素の失活が抑制されること か，経験的に古くから知られて和り，生化学や食品加工 および食品保蔵の分野で広範に底用されてきている。囪 肉タンバク質については，スケトウダラ冷倲すり身の製 造の際にスクロース款上び/またはソルピトールを添加 してタンパ質の冾凍唯性を抑制しているのがその代表 的な例である。

月向らは，グリセロールなどの直鎖梠リオール，イ， シトールなどの環状ボりオール，拈よびグルコースなど の糖の水溶液中におけるキモトリブシノーゲンやリゾチ ーム、ヌラーダン，リボヌクレアーゼAなどのタンパク 䁈と溶媒成分との相互作用の熱力学的解析を行い, ポリ オールKよるタンパク質の加熱变性抑制機满の解明を行

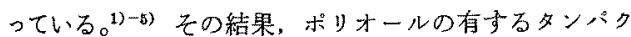
質の加熱変生抑制効果は，これらの水溶液中でタンバク 質が選択的水和を起こすことによりタンパク質の化学ボ テンシャルを増加ざせてタンパク質を安定化さ㞨るこよ であると述べている。さらに，糟については equatorial
}

位の $\mathrm{OH}$ 基（以下，e-OH と略す）が多いほど, 直鎖米 リオールについては鎖長が長い玨ど,つまり OH 基数が 多い汪ど变性抑制效果が大きいこをを明らかにしてい る。

一方，魚肉タンパタ贒については，筋原線雓タンパク 質の加熱変性に及ぼす楉，直鎖ポリオールおよび糖アル

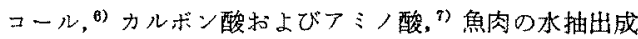
分 ${ }^{8)}$ の影響について一連の研究がなされているが，添加 したこれら溶質の構造と水分子の配列㧍よびタンパク質 分子の水和との関連性ならびに合理的で普㴜性のある夕 ンパク質変性抑制機構の解明までには至っていない。

本研究は，これまでの研究が少ないデンプン加水分解

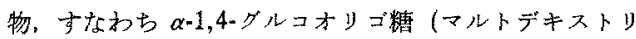
ン）の混合物である直鎖オりゴ糖や，その還元物である 還元直鎖オリゴ糖の冷凍与り身への利用を目的としてい る。魚類の筋原線維タンバク質の冷涷変性に及泟すポり オールの作用が加熱变性に対する埸合と類似しているこ とが知られているすので, 本報では，他の糖や精フルコ ールの効果と奻垶的に比較しながら，魚肉タンパク質の 分散系に执ける加熱变性に対する值鎖オリコ栯扎よび還

*1 冷涷すり身へのオリコ糖の利用に関する确究一I.

*2 三菱化成(株)総合研究所 (Research Center, Mitsubishi Kasei Co., Kamoshida, Midori, Yokohama, Kanagawa 227, Japan).

*3 三菱化成食品(株) (Mitsubishi-Kasei Foods Co., Ichikawa BLDG., Ginza, Chuo, Tokyo 104, Japan). 


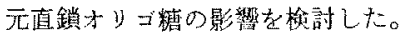

\section{実 験 方 法}

試菜 糖として值鎖オリゴ粕（墑品名「オリゴトー ス」, 三菱化成食品（株），直鎖ボリカールとして D-ソ ルビトール(特級, キシダ化学 (株)), meso-エリスリト ール(Merck 社)，糖アルマールとして還元直鎖オリゴ栯 (商品名「オリゴトース H·70」，三悲化成食品（蛛））を 用いた。

な拉，オリコトースは固形分含量 $72 \%$ のデンブン加 水分解物（デキストロース当量：DE45，数平均融合度： $\overline{\mathrm{DP}_{\mathrm{n}}}$ 2.7, 数平均分子量: $\left.\overline{\mathrm{MW}}_{\mathrm{n}} 450\right)$ でらり, 後述与る 高速庻体ク口マトグラフィー（HPLC) Kよる糖組成 はグルュース $1.8 \%$ ，マルトース 37.8\%，マルトトリ才 一ス 44.9\%。、、ルトテラオースからマルトデカオー ス要で $12.1 \%$ ，マルトウンデカオース以上 $3.3 \%$ であ る。またオリゴトース H-70は「オリゴトース」の

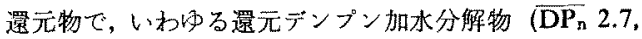
$\left.\overline{\mathrm{MW}}_{\mathrm{n}} 462\right)$ であり，ての組成は，ソルビトール $2.8 \%$ ，マ ルチトール 34.3\%，マルトトリイトール44.2\%、マルト テトライトールからマルトデカイトールをで $12.8 \%$ ママ ルトウンデカイトール以上 $5.9 \%$ である。

他の試薬は，特級品を用いた。

なお，本論文中では溶質の構造を明確にするために還 元単精の還元物を直鎖ポリオール（グリセロールやンル ビトールなと゚），還元末端が還元された楉を構成成分と する精誘道体を糖フルコール（マルチトールやラクチト ールなど)，グルコースやスクロースなどを精，直鎖ポ リオールや環状ポリオール（イノシトールなど）や糟て ルヌール，栯を総称してポリオールと記截した。

オリコ糖の HPLC HPLC 趾置は，液体クロマトグ ラフ LC-6A（島津製作所（株)）を用いだ。カラムには， スチレン・ジビニルベンゼン共重合体系の強酸性カチオ ン交換樹脂が立填された MCI GEL CK-04SS カラム $(8.0 \mathrm{ID} \times 300 \mathrm{~mm}$ ，三菱化成 (株)）を使用し，移動相は蒸 留水, 移動相の流速 $0.2 \mathrm{ml} /$ 分, カラム温度 $65^{\circ} \mathrm{C}$, 検出 は示差屈折計で $20 \mu l$ の陚料を注入して HPLCを行っ た。

筋原線維䁅濁液の調製 新鮮なマサバ Chub mackerel Scomber japonicus の背筋を細切し，グリセロールと 重量比て $1: 1$ に混合して $-25^{\circ} \mathrm{C}$ K保存して拈いた試料 から加藤らの力法 ${ }^{10)}$ b染じて筋原線維を調製し， $0.16 \mathrm{M}$ $\mathrm{KCl}$ 含有 $40 \mathrm{mM}$ Tris- $\mathrm{HCl}$ 緩衝液 (pH 7.5) K分散させ た。

筋原楾維タンパク㨁の加熱変性処理 試料惩濁液に対 して一定のモル淩度になるよらにポリオールを添加溶解 した後, その $2 \mathrm{ml}$ ずつを試験管に分注し， $35^{\circ} \mathrm{C}$ K調整
した恒温水榑内に保持し，一定時間毎に取り出して氷冷

して加熱変性処理を停止させた。

現在の泠凍すり身繁造に损いては，脱水魚肉に対して

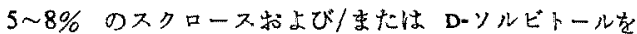
添加して魚肉タンパク質の冷凍变性を抑制しているが， これはすり身の水分量に対して $\quad 0.3 \sim 0.5 \mathrm{M}$ に相当して

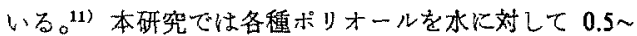
$2.0 \mathrm{M}$ といら志い濃度範用で添加した。

Ca-ATPase 活性の測定 筋原線維の Ca-ATPase 活 珄住, $0.1 \mathrm{M} \mathrm{KCl}, 5 \mathrm{~mm} \mathrm{CaCl}$, $25 \mathrm{~mm}$ Tris-Maleate 綎 街夜 ( $\mathrm{pH} \mathrm{7.0)} \mathrm{および} 1$ mM ATP の組成夜て， $25^{\circ} \mathrm{C} に$ 拈いて反応させて遊離する無機りン酸を Gomori 法"12) の変法 ${ }^{19}$ Kよ。て比色定量し，比活性 $\left(\mu \mathrm{mol} \cdot \mathrm{P}_{\mathrm{i}} / \mathrm{min}\right.$. $\mathrm{mg}$ タンパク質) を求めた。なおポリオールが共存す るとCa-ATPase 活性が見かけ上阻害されるので，実験 中に和りるタンパク質の変性を回避するために透析を行 わず， 対照試料にあ同濃度のポリオールを添加して Ca-ATPase 活性を測定し，ポリオールの影響を相殺し t心o

Ca-ATPase 活性の失活速度定数の算出 ポリオール の共存とは関係なく，Ca-ATPase の失活を一次反応式 に従って解析し，見かけの変性速度定数 $\left(\mathrm{K}_{\mathrm{D}}\right)$ ならびに

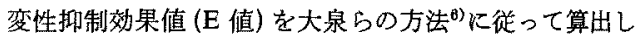
た。なお。，解析には未加熱試料の Ca-ATPase 活性に対

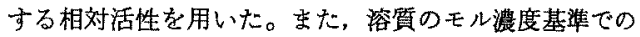
㚆性抑制効果值に加えて重量パーーセント濃度基準での変 性㧕制动果值（便宜上， $\mathrm{E}^{\prime}$ と記载する) を $\mathrm{E}$ 值の昜合 と同様な手順で求めだ。

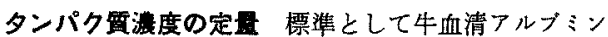
画分 Vを用いてビウレット法16で比色定量した。

\section{結果および考察}

Ca-ATPase 活性の加熱失活に及ばすポリオールの影

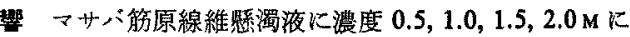
なるよらに直鎖オりゴ粕である「オリゴトース」, mesoエリスリトール，D-ソルビトール，還元值鎖オリコ糖で ある「オリゴトース H-70」をそれぞれ添加して $35^{\circ} \mathrm{C} の$ 加熱処理による Ca-ATPase 活性の失活を経時的に澌定 した。Fig. 1 にこれらのポリオールを $1.0 \mathrm{M}$ 添加した場 合の相対活性を示した。この濃度以外のすべての添加浱 度ですCa-ATPase 活性の失活は, 一次反応に従って進 行した。

次に，添加したポリオールの謴度に対して見かけの変

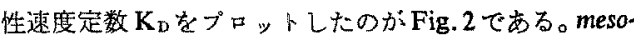
エリスリトール，およびD-ソルビトール添加系は $2.0 \mathrm{M}$ 付近まで，㨁鎖オリゴ糖と還元直鎖オリゴ栯は $1.0 \mathrm{M}$ 付 近垔で検討したが，ポリオールのモル濃度と $\mathrm{K}_{\mathrm{D}}$ との間 


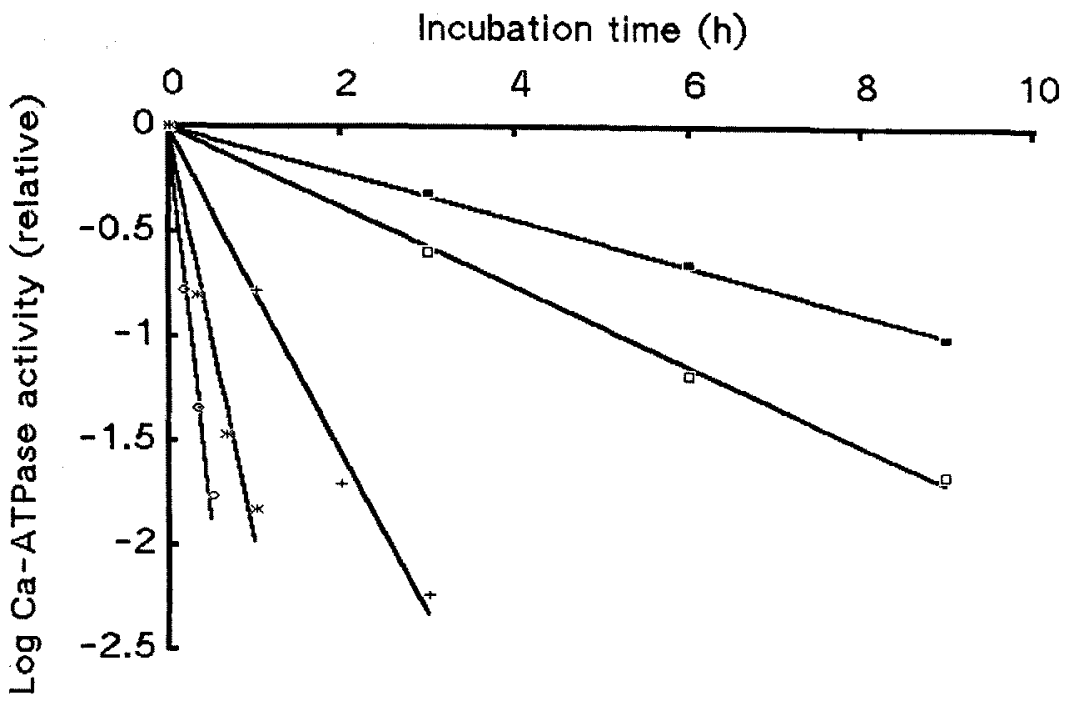

Fig. 1. Effect of linear oligosaccharides and hydrogenated linear oligosaccharides on $\mathrm{Ca}-$ ATPase activity of chub mackerel myofibrils on heating at $35^{\circ} \mathrm{C}$.

0 , control; *, $1.0 \mathrm{M}$ meso-erythritol;,$+ 1.0 \mathrm{M}$-sorbitol; $\square, 1.0 \mathrm{M}$ linear oligosaccharides; $\square, 1.0 \mathrm{~m}$ hydrogenated linear oligosaccharides.

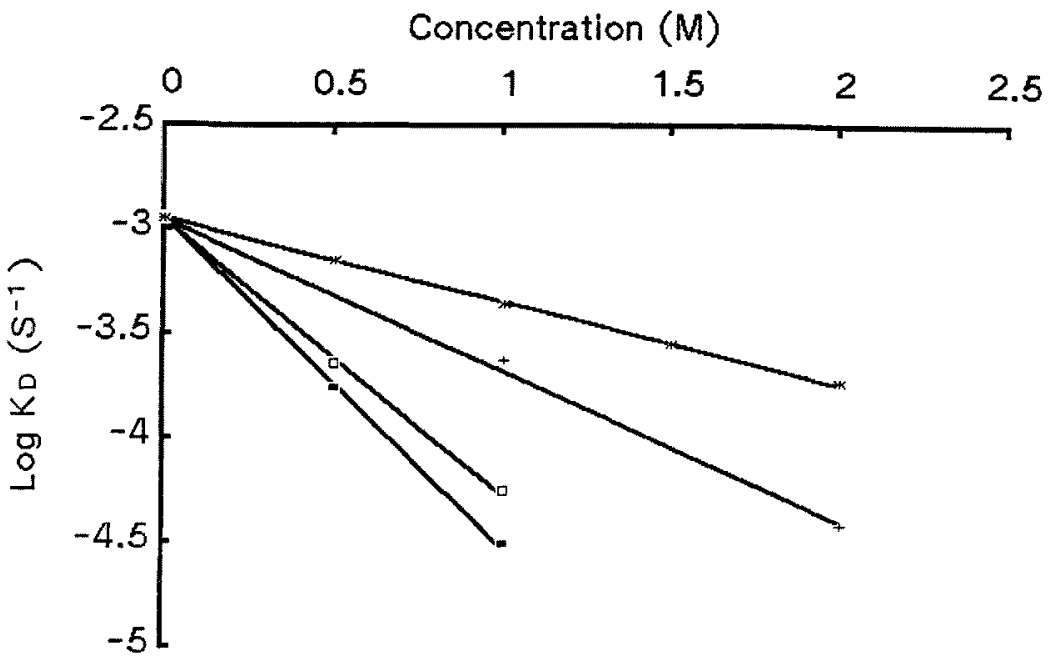

Fig. 2. The apparent rate constant for inactivation of myofibrillar Ca-ATPase as a function of concentration of linear oligosaccharides and hydrogenated linear oligosaccharides.

$\mathbf{n}$, hydrogenated linear oligosaccharides; $\square$, linear oligosaccharides; + , D-sorbitol; $*$, mesoerythritol.

\section{に面線性が認められた。}

\section{ポリオールが有する筋原線維タンパク暂の加熱变性抑}

制奻果 Fig. 2 飞示した結果から、マサバ筋原線維タン パク貿の加熱変性に対する各種ポリオールの変性抑制効

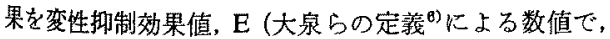
添加物 $1 \mathrm{M}$ の共存による筋原線維タンパク貿の加熱变性
速度定数の減少程度を表す。この值が大きいほど変性抑 制効果が大さい。）として算出し，大泉らの結果㫙と共に

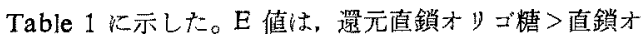
りコ糖>スクロース>D-ソルビトール>meso-エリスり トールの順に大きくなった。一方，重量パーセント灌度

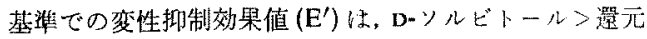


直鎖才りコ䊁>mesoーエリスりトール>スクロース>直 オリت栯の順に大きかった（Table 1)。以上のことから 今回用いた值鎖オリコ糖と還元直鎖オリゴ精は，彷来か ら冷谏寸り身に用いられていたスクロースやロ・ソルビ トールとほぼ同等の加熱变性抑制㹢果を有していること が明らかになった。また,この直鎖オリゴ糖と還元直鎖 オリゴ糖は HPLCから求めた分子量分布が洼洼等しい

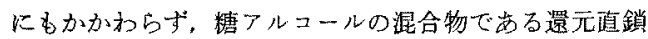
オリコ楉のうが加熱变性抑制效果が高かった。

上記の上らなポリオールによるタンパク質の加蓺变性 㧕制は，タンパク質の水和構造の㙋動茬通して担われる ことが明らか汇なってきている。 造化が進行与るにつれてタンパク質分子の蹯水性側鎖に

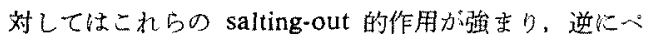
プチド主鎖に対しては salting-inの効果が強まる。その 結果としてタンパタ筫分子の柾水的相互作用が安定化さ れるので，タンパク質分子は安定化されると説明されて いる。

\section{糖の分子棈造とタンパク䁈の变性抑制効果との関連}

楛では e-OH が water-structure making 作用の支配的 因子であるため、尚この e-OH 基の割合の大きい糖はど 加熱変性㧩制效果も大きくなることが知られている。

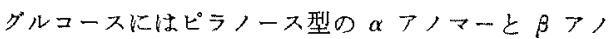
マーが存在するので，一分子中の e- $\mathrm{OH}$ 基の平均数は $4.67,4)$ スクロースの e-OH 基の平均数忙 $6.5,{ }^{1 \mathrm{~d})}$ マ トースには $\alpha$ フノマーと $\beta$ アノマーが存在するので 7.62,4) マルトトリオースでる $\alpha$ アマーと
Table 1. The protective effect of polyols against thermal denaturation of myofibrillar proteins

\begin{tabular}{|c|c|c|}
\hline \multirow[b]{2}{*}{ Solute } & \multicolumn{2}{|c|}{ Protective effect } \\
\hline & $E\left(\mathrm{M}^{-1}\right)^{* 1}$ & $\begin{array}{l}E^{\prime} \times 10^{2} \\
\left(\%^{-1}\right)^{* 2}\end{array}$ \\
\hline Glucose & $0.67^{* 5}$ & 3.72 \\
\hline Maltose & $0.63 * b$ & 1.84 \\
\hline Sucrose & $0.77 * \sqrt{5}$ & 2.25 \\
\hline Maltotriose & $1.07 * 5$ & 2.12 \\
\hline Linear oligosaccharides $* 8$ & 1.26 & 2.14 \\
\hline Glycerol & $0.08 * 6$ & 0.87 \\
\hline meso-Erythritol & 0.40 & 2.40 \\
\hline Xylitol & $0.46^{* 5}$ & 3.03 \\
\hline D-Sorbitol & 0.68 & 3.04 \\
\hline Lactitol & $1.04 * 5$ & 3.02 \\
\hline $\begin{array}{l}\text { Hydrogenated linear } \\
\text { oligosaccharides*4 }\end{array}$ & 1.57 & 2.55 \\
\hline \multicolumn{3}{|c|}{$\begin{array}{l}\text { *1 Protective effect against the inactivation of myofibrillar } \\
\text { Ca-ATPase. This parameter is the slope of linear } \\
\text { relation between } \log K_{D} \text { versus polyol concentration (M) } \\
\text { as shown in Fig. 2. }\end{array}$} \\
\hline \multicolumn{3}{|c|}{${ }^{* 3}$ Oligotose; DE $45, \overline{\mathrm{DP}}_{n} 2.7, \overline{\mathrm{MW}}_{n} 450$} \\
\hline \multicolumn{3}{|c|}{$\begin{array}{l}\text { *4 Oligotose H-70; } \overline{\mathrm{DP}_{n}} 2.7, \overline{\mathrm{MW}_{n}} 462 . \\
* 3 \text { From T. Oizumi et al.: Nippon Suisan }\end{array}$} \\
\hline
\end{tabular}

が存在するので 9.8, ${ }^{17)}$ マルトテトラオースでは $\alpha$ フ マーと $\beta$ アノマーの存在率が不明であるが, すぺて $\alpha$ アノマーとすると 13, $\beta$ フノマーとすると 14 といらよ うにグルコースを単位とした重合度が高いほど，その糖 分子中の e- $\mathrm{OH}$ 基の平均数は增加する。一方，今回用い

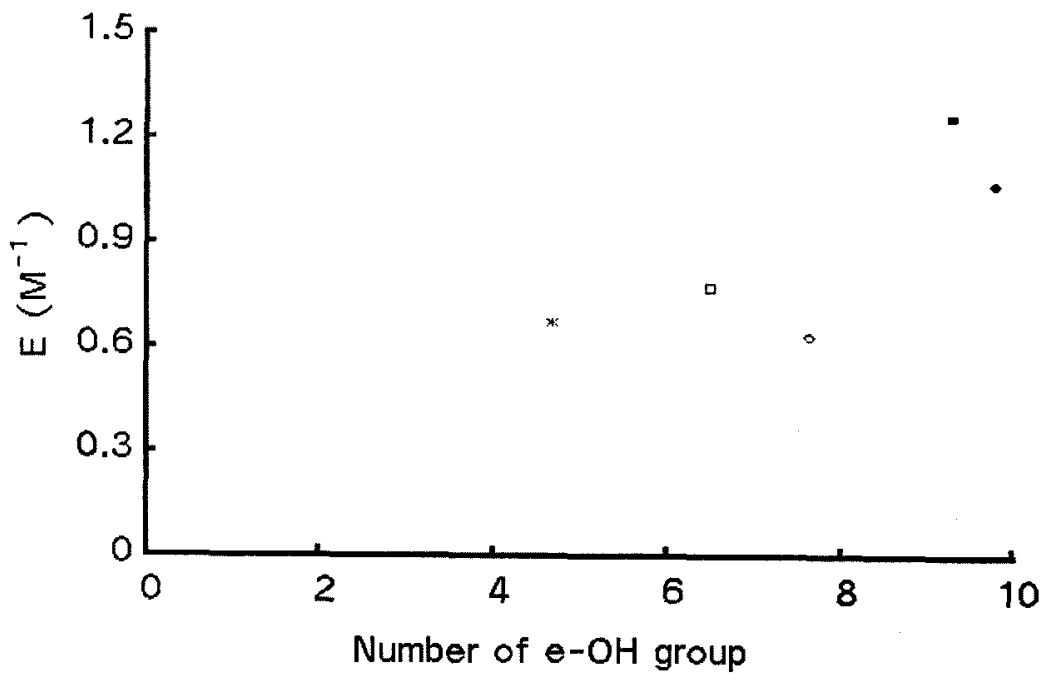

Fig. 3. Dependence of $\mathrm{E}$ on the mean number of equatorial $\mathrm{OH}$ groups per saccharide molecules.

E values are quoted from the data in Table 1.

*, glucose; $O$, maltose; $\square$, sucrose; $\bullet$, maltotriose; $\mathbf{m}$, linear oligosaccharides. 
れ直鎖オリゴ糖の e-OH 基の平均数は，グルコースのそ れが 4.67, マルトースでは 7.62, マルトトリオースでは 9.8, マルトテトラオース以上では $\alpha$ ファーと $\beta$ フ マーの存在率が不明であるが，すべて $\alpha$ ファーとして 数平均すると 9.3，マルトテトラオース以上をすべて アノマーとして数平均すると9.8である。我々の綰果打 上び大泉らの結果 ${ }^{9)}$ (Table 1)を Fig. 3 によるて示し たが, e-OH 基の平均数 9.3 (マルトテトラォ一ス以上が

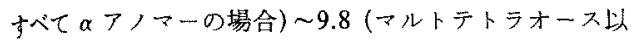

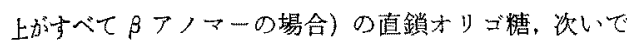
$\mathrm{e} . \mathrm{OH}$ 基の平均数 6.5 のスクロースの順に变性抑制効果 が高くなっでり，分子中の $\mathrm{e}-\mathrm{OH}$ 基数が多い糖ほど加 熱変牲抑制効果す大きくなるとら知見を支持した結果 となったしかし，e-OH 基の平均数 9.8 のマルトトり オースより的 $\mathrm{e}-\mathrm{OH}$ 基の平均数 9.3 9.8で, マルトト リオース含量が $44.9 \%$ である直鎖オリゴ粕の $\mathrm{E}$ 值の方 が大きいのは,オりゴ糖の $\mathrm{OH}$ 基の親水性水和の協調性

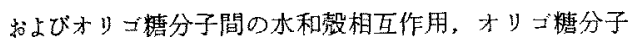
内の㔍接糖残基間の水和殼相互作用が水和殼の安定性に

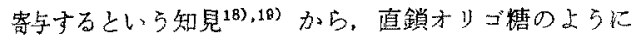
マルトデキストリンの混合物の場合にはマルトデキスト リン間の椙互作用により水の構造化が相乘的に促進され るからであると推察される。この点関しては更なる㸴 究が必要であるう。また，䲄条件に e-OH 基数が多い活 $\xi$ water-structure making 作用快大きくならないと考 充られる。それは，重合度の小さいオりゴ糖の e-OH 基 は水のトリジイト型構诘中に適合し水が構造化すると 同時に，その糖の周困のミク口粘度が增大する。すなわ ち束縛水 (不凍水) の量が增加するが，糖分子の大きさ がある程度以上になると，逆に排除体積效果により水の 楧造を乱してしまうとともにオリざ糖や多精類では $\mathrm{CH}$ 基があるコンフォメーションをとれば, 蹯水性領域 を采に生成させてしまうことが指摘されている201からで

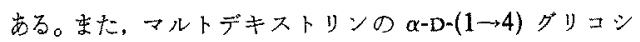
ド結合の linkage rotation 值 ${ }^{21}$ が重合度 4 まで大きく 低下し，重合度 7 以上ではアミロースのとれと同籍にな り重合度 6 を境界にしてマルトデキストリンのコンフ カターションの自由度が低下して構造を形成することが 報告されている。従って，マルトデキストリンに和い ては e-OH 基の割合の大きい糖，すな⿰力口重合度が高い ほど加熱変性㧕制効果も大きくなるといら傾问は，女い ぜい重合度 6 硅度までであると考克られる。

直鎖ポリオールおよひ糖アルコールの分子構造とタン パク犋の変性抑制効果との関連 直鎖ポリオールでは, 鑤長吕長くなるにつれて，すなわち分子中の $\mathrm{OH}$ 基数が 多くなるにつれて water-structure making 作用が大き くなり眯水性相互作用が安定化されるが，逆にペプチド
間水妻結合を安青化する效果性弱る ${ }^{22)}$ と理解されてい 名。

グリセロールの $\mathrm{OH}$ 基数休 3, meso-xリスリトール では 4, キシリトールては 5,D-ソルビトールでは 6 と いらよらにポリオール鎖長が長い玨ど，そのポリオール 分子中の $\mathrm{OH}$ 基数俚堌加する。我々の結果では, D-ソル ビトール，meso-エリスりトールの順に变性抑制効果が 高くなって㧍り (Table 1), $\mathrm{OH}$ 基数の多い直鎖ポリオー 儿攺ど加熱変性排制効果も大きくなるといら知見を支持 した結果となった。さらに大泉らの結果引噺せると， 奥肉筋原線維夕ンパク質の加熱変性抑制効果は D-ソル ビトール>キンリトール>meso-エリスりトール>ダリ セロールの順に大きいことになる (Fig. 4)。李た, 糖つ ルニールの重合度といら観点かららは, 重合度 $10 \mathrm{D}-$ ソ ルビトールの OH 基数は 6 , 重合度 2 のマルチトール ( $\alpha$-Glc $(1 \rightarrow 4)$ Sor) では OH 基数 9 で e-OH 基数 4, クチトール ( $\beta-\mathrm{Gal}(1 \rightarrow 4)$ Sor) では $\mathrm{OH}$ 㫷数 9 で e-OH 基数 3, 重合度 3 のマルトトりイトール $(\alpha-\mathrm{Glc}(1 \rightarrow 4) \alpha$ Glc (1-4) Sor) では OH 基数 12 て e-OH 基数 7 と いらよ5に重合度が高い汪ど，その糖アルコール分子中

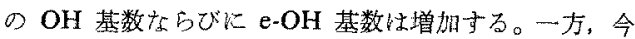
回用いた還元值鎖オリゴ糖の $\mathrm{OH}$ 基数拈よび e-OH 基 数は，各成分の俻を数平均して求めるとそれぞれ 11.2,

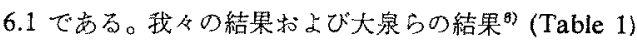
を併せるとマルチトール和よびマルトトリイトールの結 果が欠損するが，Fig. 4 に示したよらに魚肉等原線維夕 ンペク質の加熱变性抑制效果は，還元直鎖オリゴ糖>ラ クキトール>D-ソルビトールの順に大きいことになる。 寸なわち， $\mathrm{OH}$ 基数ならび $\mathrm{F} \mathrm{e}-\mathrm{OH}$ 基数が多い糖了ルコ ールほど加熱変性抑制效果も大さくなった。さらにリボ ヌクレナービ A の加熱変性抑制胶果がマルチトールう マルトース>グルコースうD-ソルビトールであったとい 5月向らの結果卓を加味すると、マルトデキストリン 類の緢アルコールでは加熱変性㧕制効果が構成単糖の重

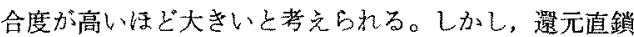
オリゴ糖の構成成分であるマルトデキストリン類の糖つ ルコ一ル間の相互作用により水の構造化が相乘的に促進 されるかどらか恃不明である。さらに，精類の場合之同

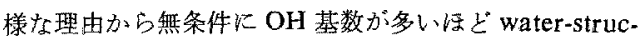
ture making 作用は大きくならないであるう。

こ机までに述べてきたように，マルトデキストリン類 の混合物である直鎖オリゴ榶あるい忧々の還元物である 僄元值鎖オりゴ精をタンパク質変制拥制の目的で使用す る場合に法，分子中の $\mathrm{OH}$ 基数や $\mathrm{e}-\mathrm{OH}$ 基数, $\mathrm{OH}$ 基 数と $\mathrm{e}-\mathrm{OH}$ 基数のバランス扣よび分子形状の指摽とな る重合度分布が典要な因子であることが明らかになっ た。しかし、いずれのポリホール閒の相互作用に上り承 


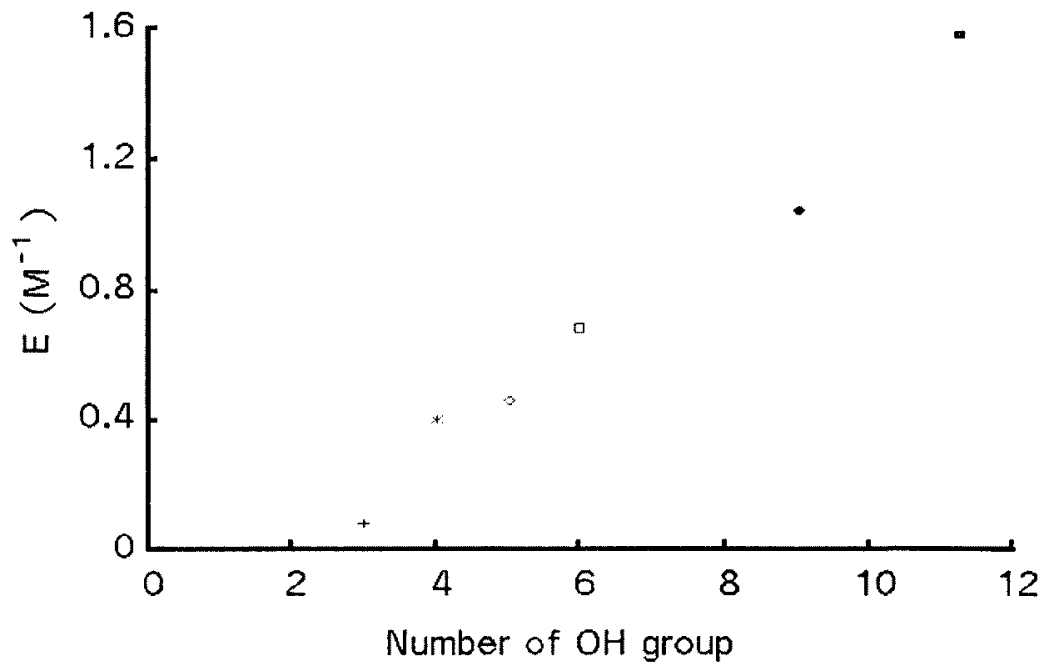

Fig. 4. Plots of $\mathrm{E}$ as a function of the number of $\mathrm{OH}$ groups per linear polyol and polyhydric alcohol molecules.

$E$ values are quoted from the data in Table 1 .

+ , glycerol; $*$, meso-erythritol; $O$, xylitol; $\square$, D-sorbitol; $\mathbf{0}$, lactitol; $\mathbf{n}$, hydrogenated linear oligosaccharides.

の構造化が相乗的に促進されるのか，あるいはどの成分 の効果が高いのか関しては，高純度のポリオールを用 いて 1 成分系, 2 成分系, 次いて 3 成分系といら具合 以共存するポリオールの種類を增加させて，そのタンパ ク質変性抑制効果を検討していくことが考えられる。こ の分野での上記に記截したよらな更なる研究が期待され 万。

な和，本研究の最終目的である冷涷すり身にお忛る評 価結果は，追って報告する。

\section{韵 辞}

本矿究を行ならにあたり，御指尊を賜った北海道大学 水座学部教授 新井健一博士ならびに青森紧水産物加工 研究所課長 福田 裕博士（現在，青森県内水面水産試 験場）に深く感謝申し上げる。また，ポリオールによる タンハクク質変珄抑制機構に関して貴重なる御示崚ならび に御意見を頂いた名古屋大学農学部助教授 月向邦彦博 士に㳭く御礼申し上げる。

\section{文献}

1) K. Gekko and S. N. Timasheff: Biochemistry, 20, 4667-4676 (1981).

2) K. Gekko and T. Morikawa: J. Biochem., 90, 51-60 (1981).

3) K. Gekko: J. Biochem., 91, 1197-1204 (1982).

4) K. Gekko and S. Koga: J. Biochem., 94, 199-
205 (1983).

5) K. Gekko and Y. Idota: Agric. Biol. Chem., 53, 89-95 (1989).

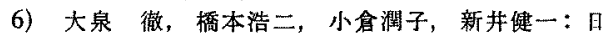
水誌，47，901-908 (1981).

7) 大泉 徹, 奈良泰信, 新井健一：日水誌，50, 875-882 (1984).

8）大泉 徹, 黑田晢弘, 新井健一：日水誌, 51, 1717-1722 (1985).

9) 松本行司, 新井健一：日水誌，52，2033-2038 (1986).

10) 加藤 登, 内山 均, 塚本志朗, 新井健一：日 水誌，47，857-867 (1977).

11）新井煡一：水産水り製品䓅術研究会誌，10，385394 (1985).

12) G. Gomori: J. Lab. Clin. Med., 27, $955-960$ (1942).

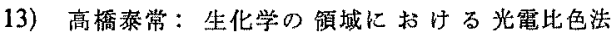
(関根隆光編)，南光堂，東京，1962，pp.13-14.

14) A. G. Gornall, C. T. Bardwill, and M. M. David: J. Biol. Chem., 177, 751-766 (1946).

15) M. J. Tait, A. Suggett, F. Franks, S. Ablett, and P. A. Quichenden: J. Solution Chem., 1, 131-151 (1972).

16) H. Uedaira and H. Uedaira: Bull. Chem. Soc. Jpn., 53, 2451-2455 (1980).

17) H. Uedaira, M. Ishimura, S. Tsuda, and H. Uedaira: Bull. Chem. Soc. Jpn., 63, 3376-3379 (1990).

18) 矢野由紀, 㴬名堂昌信: $T I G G, 2,156-167$ (1990). 
19) K. Miyajima, M. Sawada, and M. Nakagaki: Bull. Chem. Soc. Jpn., 56, 1954-1957 (1983).

20) A. Sugget: in "Water, A Comprehensive Treatise" (ed. by F. Franks), Vol. 4, Plenum Press,
New York, 1975, pp. 519-567.

21) D. A. Rees: $J$. Chem. Soc., B877 (1970).

22) K. Gekko: I. Biochem., 91, 1197-1204 (1982). 